\title{
Prototype Pemilah Buah Stroberi Otomatis menggunakan Kamera berbasis Arduino Uno
}

\author{
Nurhikma Arifin*1, Dian Megah Sari, Amalia Chairy ${ }^{3}$ \\ ${ }^{1,2,3}$ Program Studi Teknik Informatika Universitas Sulawesi Barat \\ E-mail: *11nurhikma_arifin@ unsulbar.ac.id, ${ }^{2}$ dianmegahsari@unsulbar.ac.id, \\ 3amaliachairy@unsulbar.ac.id
}

\begin{abstract}
Abstrak
Perkembangan teknologi yang pesat telah membawa dampak yang besar pada sektor agroindustri. Proses pemilahan buah yang dilakukan secara manual telah mulai digantikan oleh mesin pemilah otomatis. Penelitian ini bertujuan untuk membuat prototype pemilah buah stroberi otomatis menggunakan kamera berbasis arduino uno untuk keperluan otomatisasi industri. Prototype ini menggunakan hardware seperti conveyor belt, box, LED strip, Arduino Uno, Motor Servo SG90 9G Towerpro dan kamera Logitech C920. Data stroberi yang diambil kamera otomatis diolah untuk proses klasifikasi menggunakan algoritma Support Vector Machine (SVM). Arduino Uno akan mengontrol motor servo untuk memilah stroberi berdasarkan hasil klasifikasi algoritma SVM ke dalam 2 jalur, yaitu stroberi yang memenuhi standar dan stroberi yang tidak memenuhi standar. Kategori stroberi yang memenuhi standar adalah stroberi yang sudah matang sedangkan stroberi yang tidak memenuhi standar adalah stroberi belum matang, setengah matang dan busuk. Data yang digunakan terdiri dari 280 data latih dan 80 data uji. Hasil penelitian menunjukkan bahwa alat ini mampu memilah stroberi dengan dengan baik dengan hasil rata-rata akurasi $95 \%$.
\end{abstract}

Kata kunci-Stroberi, Conveyor Belt, Arduino Uno, Motor Servo, Support Vector Machine

\begin{abstract}
Rapid technological developments have had a major impact on the agro-industrial sector. Fruit sorting process which used to be done manually has been gradually replaced by automatic sorting machines. This study aims to create an automatic strawberry sorting machine using Arduino Uno and camera for industrial automation purposes. This prototype uses hardware such as a conveyor belt, box, LED strip, Arduino Uno, Servo Motor SG90 9G Towerpro and a Logitech C920 camera. Strawberry data taken by the camera are automatically processed for the classification using the Support Vector Machine (SVM) algorithm. The Arduino Uno then distributes the strawberries using servo motor based on the results of the SVM classification into 2 tracks for strawberries that meet the standards and strawberries that do not meet the standards. The category of strawberries that meet the standards are ripe strawberries, while those that do not meet the standards are unripe, half-ripe and rotten strawberries. The data consisted of 280 training data and 80 test data. The results showed that the prototype was able to sort strawberries well with an average accuracy of $95 \%$.
\end{abstract}


Kata kunci-Strawberry, Conveyor Belt, Arduino Uno, Motor Servo, Support Vector Machine

\section{PENDAHULUAN}

Kemajuan teknologi komputer telah menyentuh sektor pertanian dan telah digunakan di hampir semua tahap produksi, mulai dari tahap pengolahan lahan, penanaman, hingga pascapanen. Penggunaan teknologi yang tepat dan efektif selama periode pascapanen dapat memberikan manfaat yang efisien untuk peningkatan kualitas dan kuantitas produk pertanian [1]. Sementara operasi skala besar dapat mengambil manfaat dari investasi dalam mesin penanganan yang mahal dan perawatan pascapanen berteknologi tinggi, seringkali opsi ini tidak praktis untuk produksi skala kecil. Sebaliknya, teknologi sederhana dan berbiaya rendah sering kali lebih sesuai untuk petani lokal, operasi komersial dengan sumber daya terbatas, petani yang terlibat dalam pemasaran langsung, serta untuk pemasok ke eksportir di negara berkembang.

Seiring dengan berkembangnya teknologi, teknik manual untuk menyortir buah diganti dengan mesin yang dilengkapi dengan teknik komputer visi dan kecerdasan buatan. Para peneliti dan penemu merancang berbagai mesin yang berbeda untuk buah untuk mengurangi usaha manusia. Mesin sortir untuk buah-buahan seperti apel, mangga, kentang, jeruk, dan sebagainya sudah dirancang dan dibuat oleh peneliti sebelumnya. Ahmadi dkk. dalam [2] merancang mesin penyortir buah-buahan berbentuk bulat. Mesin ini menggunakan conveyor belt dan mekanisme belt-and-roller serta ditenagai oleh dua motor listrik $0,37 \mathrm{~kW}$. Mesin ini juga menggunakan gearbox yang memberi daya pada belt dan roller sehingga memiliki tiga kecepatan putar berbeda. Mesin tersebut diuji menggunakan dua jenis apel dan satu jenis jeruk, yang menunjukkan akurasi 95,28\% dan 92,48\% untuk masing-masing jenis apel dan 94,28\% untuk jeruk. Rancang sistem oleh Kamthe dkk. [3] juga menggunakan konsep yang sama dengan peneliti sebelumnya, namun sistem ini dibuat untuk menggolongkan berbagai jenis bawang. Sistem ini menggunakan parameter berupa kecepatan putar conveyor dan feeding rate, dimana efisiensi maksimum diperoleh pada kecepatan $55 \mathrm{rpm}$ dan feeding rate $125 \mathrm{~kg} / \mathrm{jam}$. Sementara itu, sistem yang dibuat Adamu dkk. [4] dapat mendeteksi dan mengklasifikasi berbagai jenis buah, diantaranya mangga, jeruk, lemon, apel, dan tomat, serta memberikan akurasi sebesar $90 \%$.

Salah satu hasil pertanian yang dikembangkan pada sektor agroindustri adalah stroberi. Waktu panen yang optimal stroberi buah diperkirakan berdasarkan perkembangan warna permukaan. Buah stroberi dapat dipanen pada tahap yang berbeda selama perkembangan warna yaitu ketika permulaan munculnya warna kemerahan, setengah berwarna, tiga perempat berwarna dan berwarna merah penuh. Berdasarkan penampilan pertama dan perkembangan selanjutnya berwarna merah. Indeks kematangan yang digunakan untuk panen adalah warna merah yang dihasilkan dari sintesis antosinin yang sesuai dengan setengah atau tiga perempat dari buah [5].

Selama ini telah banyak dibuat sistem penyortir stroberi menggunakan kecerdasan buatan dan machine learning, seperti yang telah dibangun oleh Ishikawa dkk. [6], Mahendra dkk. [7], dan Ibba ddk. [8]. Namun prototype mesin penyortir juga diperlukan untuk dapat diimplementasikan seutuhnya. Oleh karena itu, penelitian ini dibuat untuk merancang dan membangun sebuah prototype alat pemilah buah stroberi otomatis menggunakan sistem kendali berbasis Arduino menggunakan kamera.

\section{METODE}

\subsection{Desain Sistem}

Adapun desain prototype pemilah buah stroberi otomatis yang dilakukan pada penelitian ini diilustrasikan pada Gambar 1. 


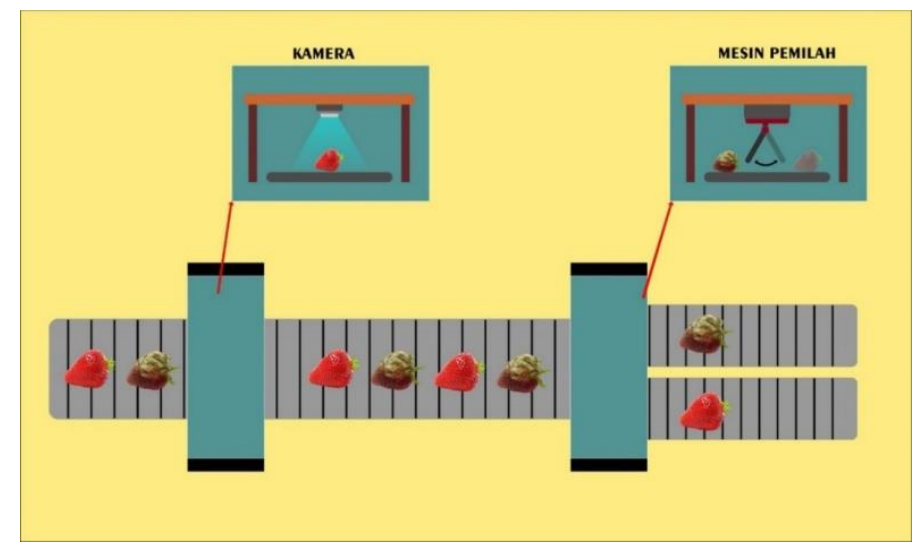

Gambar 1 Desain prototype pemilah buah stroberi otomatis

Prototype pemilah buah stroberi otomatis dibuat dalam bentuk prototype untuk keperluan otomatisasi industri. Alat ini akan memilah stroberi menjadi 2 bagian berdasarkan kematangan stroberi yaitu stroberi yang memenuhi standar dan stroberi yang tidak memenuhi standar. Kategori stroberi yang memenuhi standar adalah stroberi yang sudah matang sedangkan stroberi yang tidak memenuhi standar adalah stroberi belum matang, setengah matang dan busuk. Prototype ini menggunakan hardware seperti conveyor belt, box, LED strip, Arduino Uno, Motor Servo SG90 9G Towerpro dan kamera Logitech C920.

\subsubsection{Conveyor Belt'}

Penggunaan Conveyor belt telah lama diaplikasikan dalam berbagai sektor industri. Pada penelitian ini Conveyor belt digunakan untuk memudahkan dalam pemindahan stroberi sehingga membantu meningkatkan produktivitas, menghemat biaya tenaga kerja, dan mengurangi waktu tunggu. Desain conveyor belt mencakup dua katrol bermotor dengan bahan konveyor dilingkarkan di atasnya. Katrol beroperasi pada kecepatan yang sama dan bergerak ke arah yang sama untuk mengaktifkan gerakan sabuk konveyor. Conveyor belt ini dapat memindahkan stroberi dalam jumlah besar dengan cepat dan andal. Warna Conveyor belt yang digunakan pada penelitian ini adalah hitam sehingga memudahkan sistem dalam mendeteksi objek stroberi. Perbedaan yang signifikan antara objek stroberi dan warna Conveyor belt menghasilkan deteksi lebih akurat.

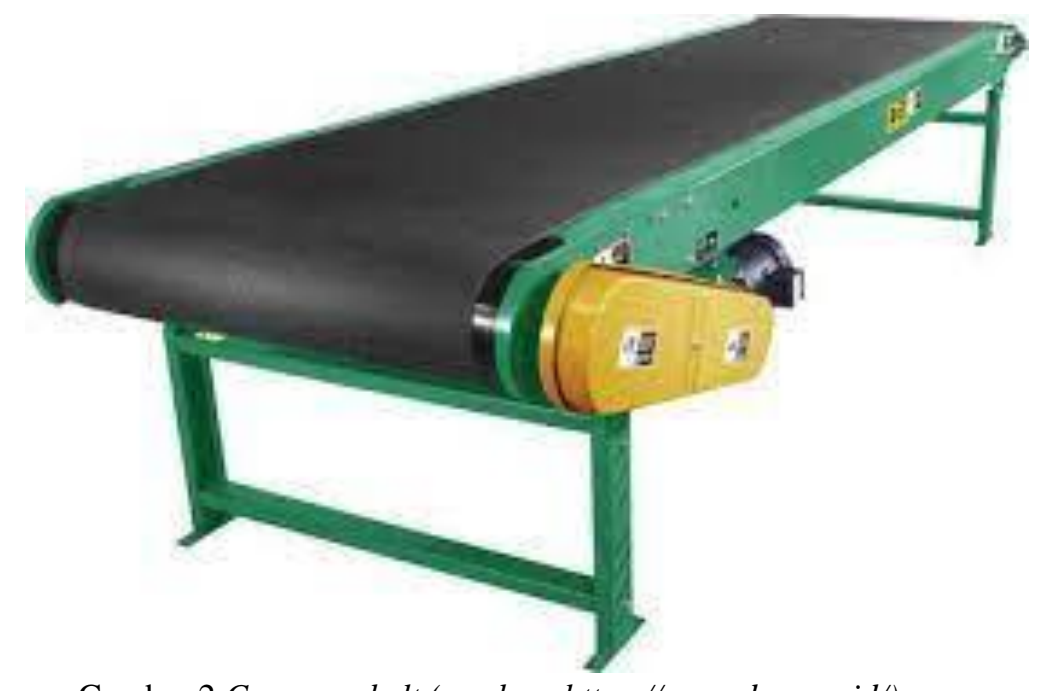

Gambar 2 Conveyor belt (sumber: https://www.dnm.co.id/) 


\subsubsection{LED Strip}

Lampu LED strip merupakan model lampu memanjang dengan penggunaan lampu chip SMD LED dengan banyak varian warna. Listrik yang digunakan bertegangan 5 Volt. Pada penelitian ini menggunakan 2 Lampu Led Strip yang di pasang pada masing-masing sisi box. Pemilihan lampu LED strip disebabkan karena cahaya dari lampu LED strip di program sesuai keinginan dan dipotong menjadi lebih kecil sesuai kebutuhan karena tingkat kecerahan cahaya sangat berpengaruh terhadap hasil klasifikasi. Warna LED strip pada penelitian ini adalah putih sehingga tidak berpengaruh terhadap warna objek stroberi.

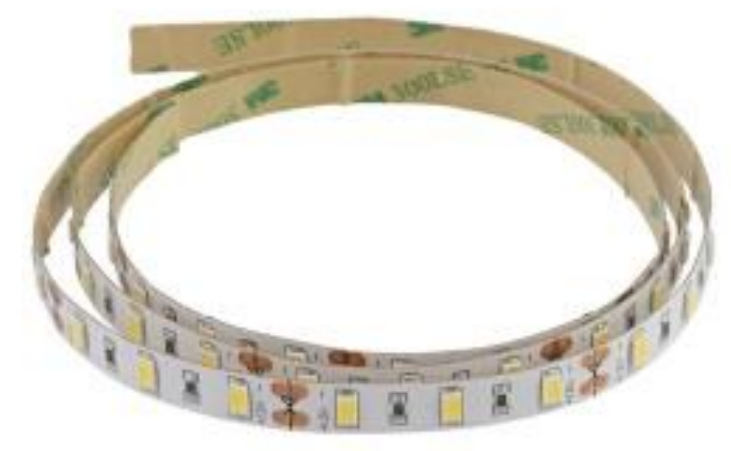

\subsubsection{Arduino Uno}

Gambar 3 LED Strip

Arduino Uno adalah board mikrokontroler berbasis ATmega328. Memiliki 14 pin input dari output digital dimana 6 pin input tersebut dapat digunakan sebagai output PWM dan 6 pin input analog, $16 \mathrm{MHz}$ osilator kristal, koneksi USB, jack power, ICSP header, dan tombol reset. Pada penelitian mikrokontroler digunakan dengan menghubungkan Board Arduino Uno ke komputer dengan menggunakan kabel USB dan perangkat lunak yang digunakan untuk menulis dan menyusun kode ke board Arduino adalah Arduino IDE (Integrated Development Environment).

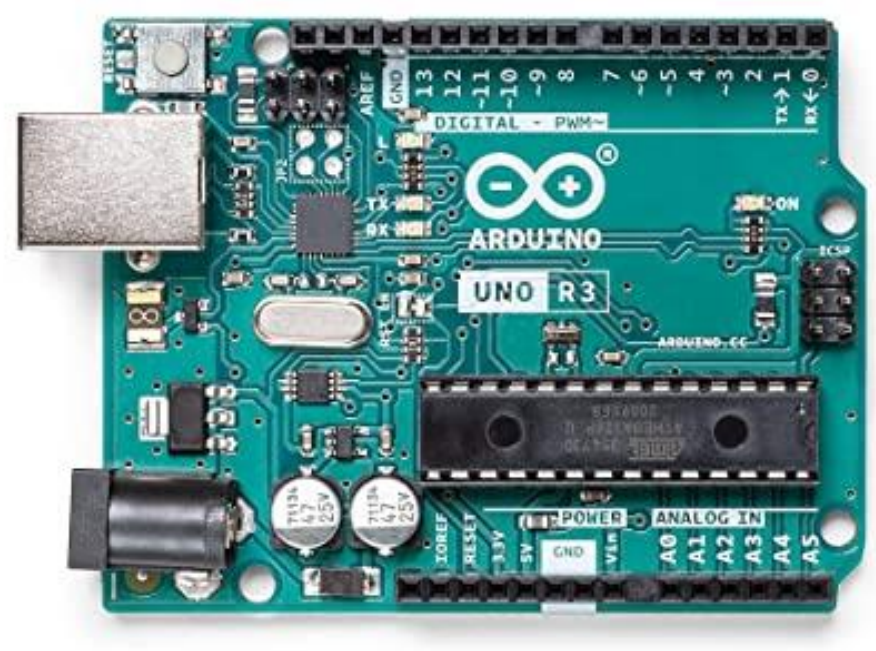

Gambar 4 Arduino Uno (sumber: https://spiceman.net//) 


\subsubsection{Motor Servo SG90 9G Towerpro}

Servo mini TowerPro SG90 digunakan pada penelitian ini karena servo mini TowerPro SG90 ringan, berkualitas tinggi, dan cepat. Servo ini bekerja dengan hampir semua sistem kontrol radio dan dilengkapi carbon fiber gears yang membuat motor servo jauh lebih ringan daripada motor gear logam yang sama. Servo digital ini mampu menerima dan memproses sinyal PWM lebih cepat dan lebih baik. Ini melengkapi sirkuit internal canggih yang memberikan torsi yang baik, daya tahan, dan pembaruan yang lebih cepat sebagai respons terhadap kekuatan eksternal.

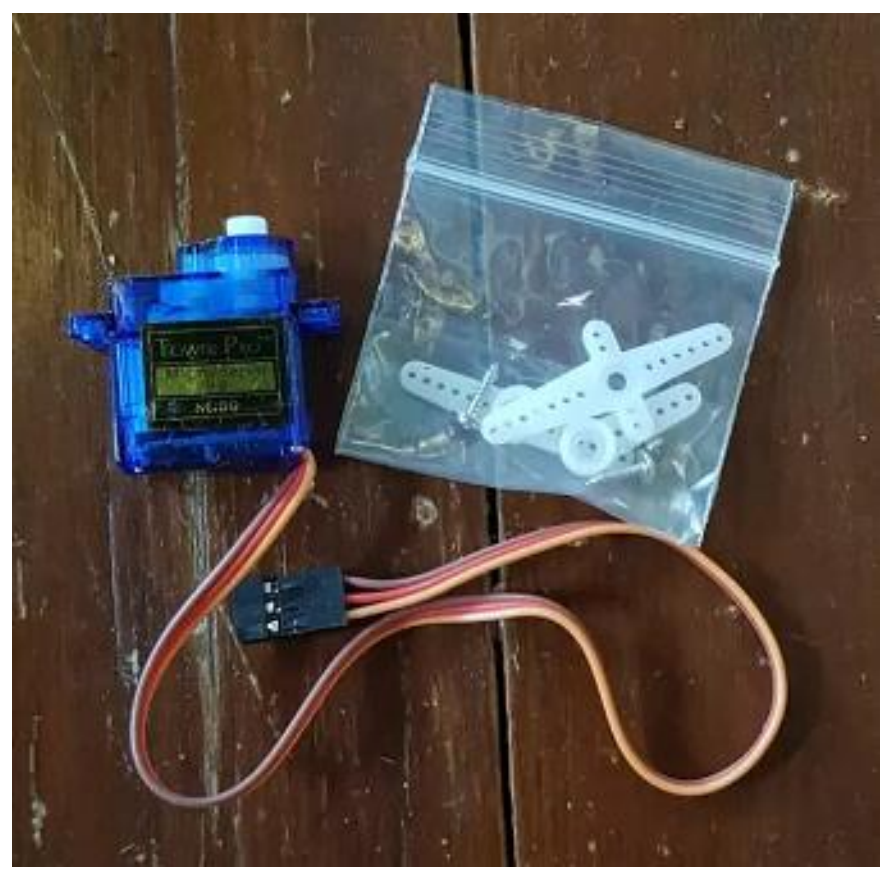

Gambar 5 Motor Servo SG90 9G Towerpro

\subsubsection{Kamera Logitech C920}

Pada penelitian ini menggunakan kamera Logitech yang memiliki keunggulan video full HD sangat tajam dan detail (1080p pada 30fps) dengan lensa kaca full HD. Kamera ini dapat menangkap gambar stroberi dengan jelas dan mengirimkan secara real time ke komputer.

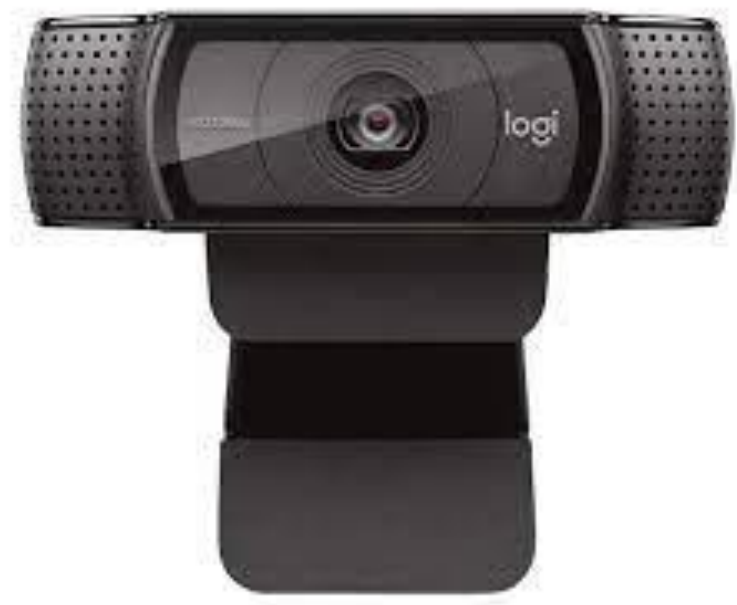

Gambar 6 Kamera Logitech C920 (sumber: https://www.logitech.com/) 


\section{2 Alur Sistem}

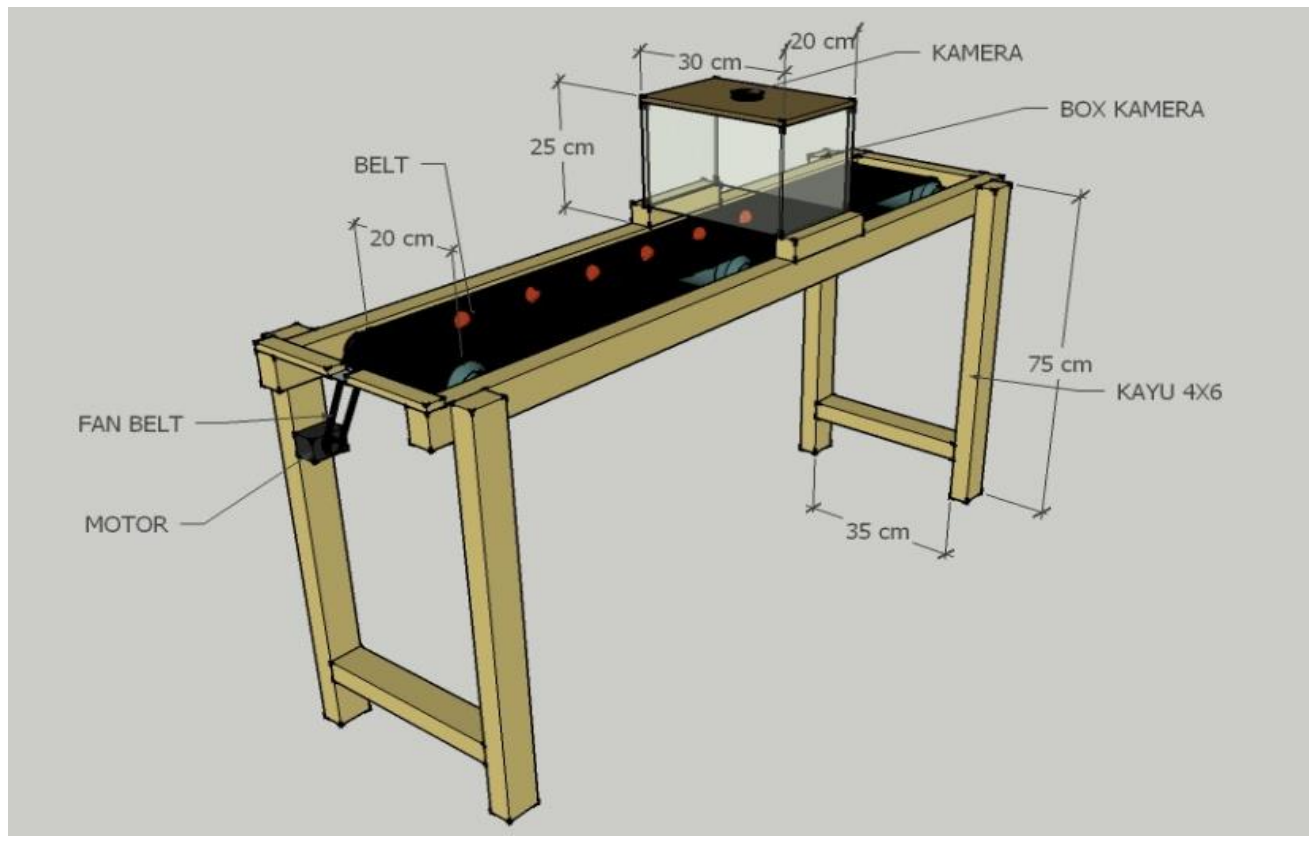

Gambar 7 Prototype Pemilah Buah Stroberi Otomatis

Prinsip kerja alat pemilah buah stroberi otomatis menggunakan kamera berbasis Arduino uno pada Gambar 7 yaitu conveyor belt bergerak membawa stroberi dengan kecepatan gearbox motor $20 \mathrm{rpm}$ menuju posisi kamera yang terpasang pada box. Stroberi direkam dengan posisi kamera menghadap lurus ke bawah dengan jarak antara kamera dan objek stroberi adalah $25 \mathrm{~cm}$. Data yang diambil kamera otomatis diolah untuk proses klasifikasi menggunakan algoritma Support Vector Machine (SVM). Arduino Uno akan mengontrol motor servo untuk memilah stroberi berdasarkan hasil klasifikasi algoritma SVM ke dalam 2 jalur, yaitu stroberi yang memenuhi standar dan stroberi yang tidak memenuhi standar. Jika hasil klasifikasi belum matang dan setengah matang maka Arduino Uno memberi intruksi untuk palang servo bergerak ke kanan yaitu jalur yang tidak memenuhi standar sedangkan jika hasil klasifikasi buah stoberi matang maka palang servo bergerak ke kanan yaitu jalur yang memenuhi standar.

\section{2.1 Data Latih}

Data latih diambil dari data stroberi yang direkam melalui kamera yang terpasang pada box alat pemilah buah stroberi. Data yang digunakan pada penelitian ini terdiri dari 70 data untuk masing-masing kategori Belum matang, setengah matang, matang dan Busuk. Data ini kemudian diproses untuk mendapatkan model SVM yang digunakan dalam memprediksi kategori tingkat kematangan buah pada proses uji.

\section{2.2 Data Uji}

Data uji terdiri dari 20 data untuk masing-masing kategori Belum matang, setengah matang, matang dan Busuk. Uji coba yang dilakukan pada penelitian ini yaitu buah stroberi yang digunakan untuk data uji diletakkan secara acak diatas conveyor Belt. Conveyor Belt yang bergerak membawa stroberi menuju kamera yang terpasang pada box. Hasil klasifikasi algoritma SVM akan menentukan jalur buah stoberi yaitu jalur memenuhi standar (MS) dan tidak memenuhi standar (TMS). Hasil uji coba prototype pemilah stroberi ditunjukkan pada Gambar 8. 


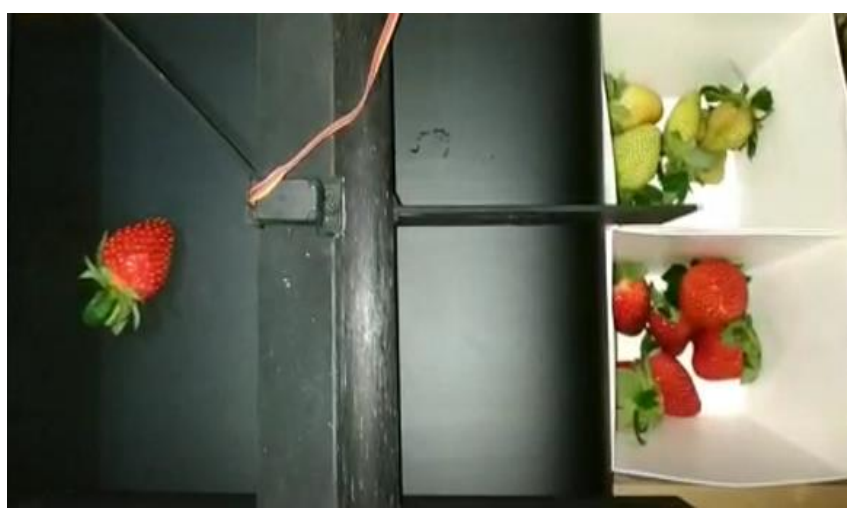

(a)

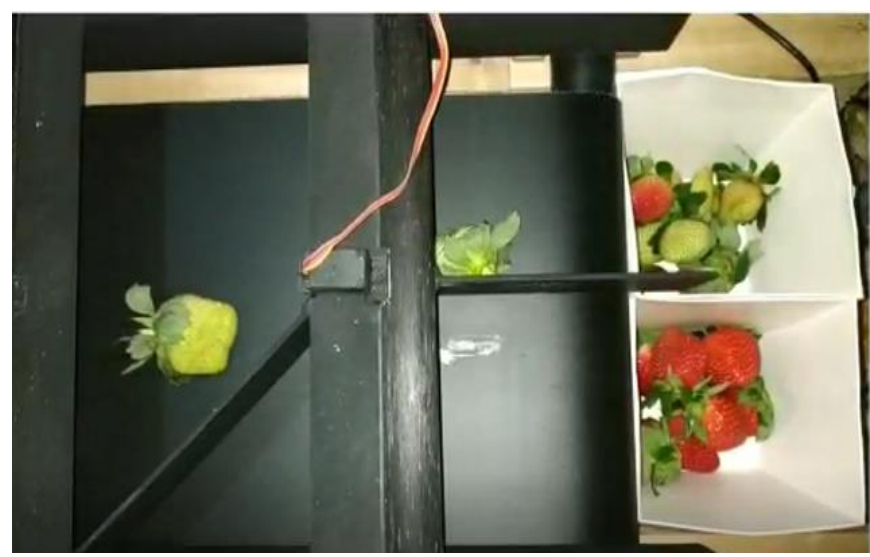

(b)

Gambar 8 Prototype Pemilah Stroberi Otomatis (a) Memenuhi Standar; (b) Tidak Memenuhi Standar

\section{HASIL DAN PEMBAHASAN}

Prototype pemilah buah stroberi otomatis pada penelitian ini menggunakan 280 data latih dan 80 data uji. Terdapat 2 jalur pada alat pemilah ini yaitu jalur Tidak Memenuhi Standar (TMS) dan jalur Memenuhi Standar (MS). Hasil uji coba yang dilakukan ditunjukkan pada Tabel 1.

Tabel 1. Hasil uji coba protoype pemilah buah Stroberi otomatis

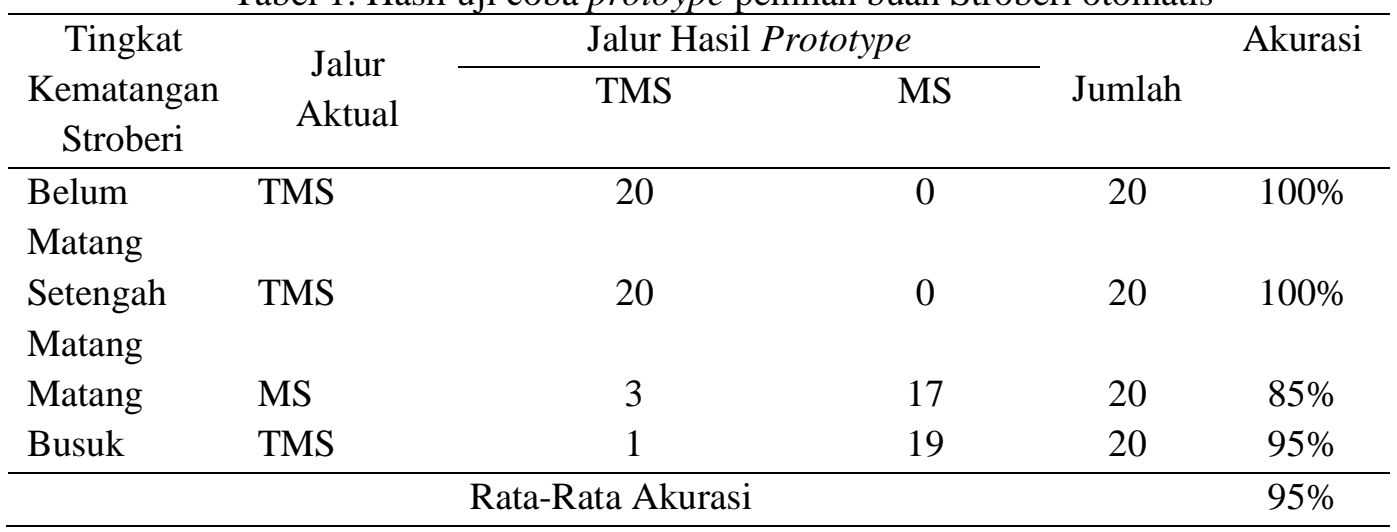

Berdasarkan hasil uji coba rata-rata akurasi adalah 95\%, kesalahan jalur hasil protoype terdapat pada buah stroberi matang dan busuk. Hal ini disebabkan karena hasil klasifikasi algortima SVM 
yang tidak sesuai. Kesalahan ini disebabkan oleh beberapa faktor yaitu kedekatan fitur warna buah, posisi dan kondisi daun stroberi. Kesalahan hasil klasifikasi ditunjukkan pada Tabel 2.

Tabel 2. Kesalahan Hasil Klasifikasi

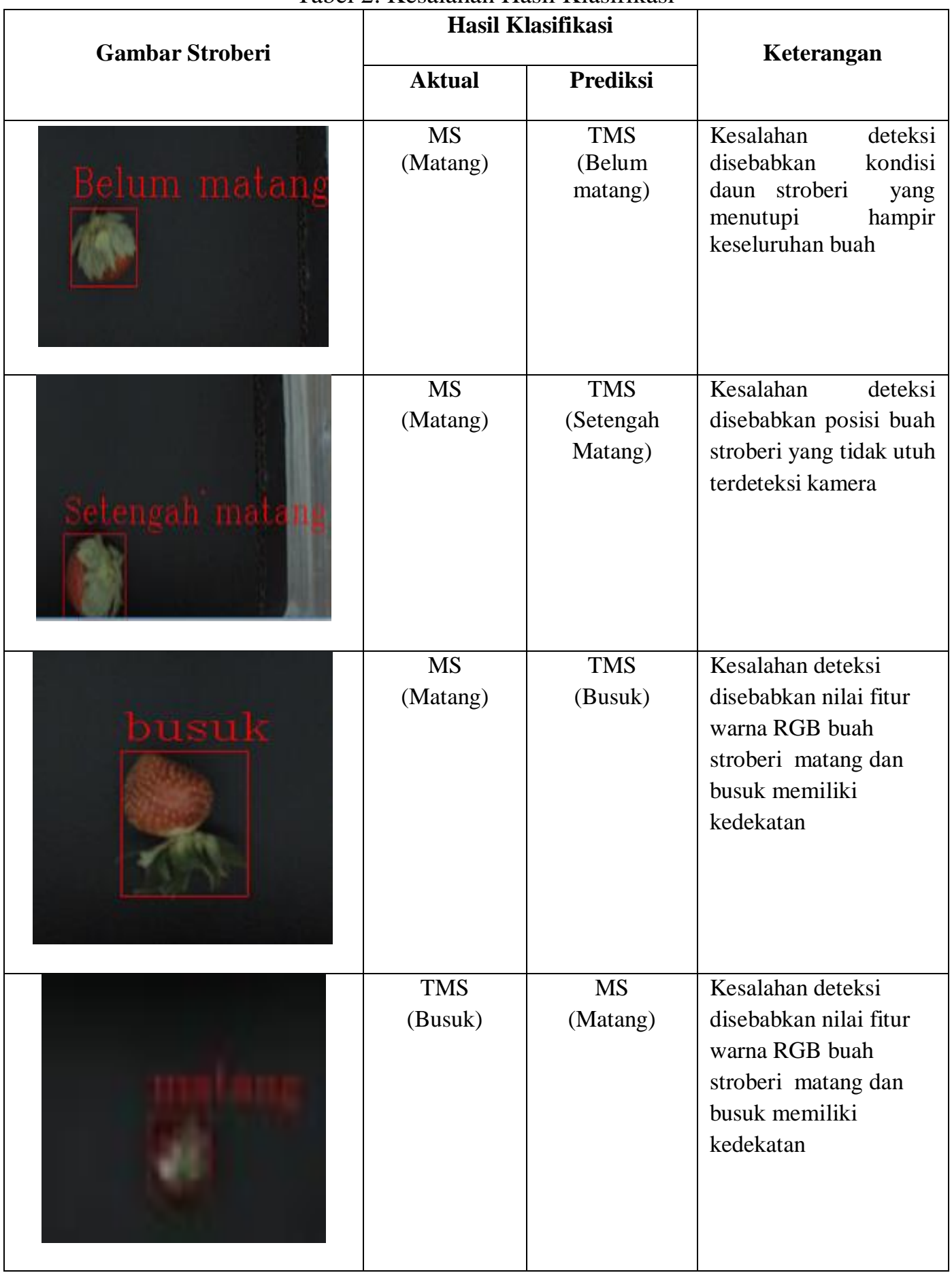


Prototype Pemilah buah stroberi menggunakan kamera berbasis Arduino Uno pada penelitian ini dapat di implementasikan dengan baik dengan hasil rata-rata akurasi 95\%. Alat ini dapat membantu meringankan pekerjaan manusia sehingga dapat digunakan untuk keperluan otomatisasi industri.

\section{REFERENSI}

[1] A. Abbas dan R. N. Suhaeti, "Pemanfaatan Teknologi Pascapanen Untuk Pengembangan Agroindustri Perdesaan di Indonesia," Forum Penelitian Agro Ekonomi, Vol. 34 No. 1, p. 21, Jul. 2016.

[2] V. F. Ahmadi, P. Ziyaee, P. Bazyar, and E. Cavallo, "Development and Testing of a LowCost Belt-and-Roller Machine for Spheroid Fruit Sorting," AgriEngineering, Vol. 2, pp. 596-606, 2020. Doi:10.3390/agriengineering2040040.

[3] N. V. Kamthe, A. M. Kapare, R. S. Kamble, A. H. Kamble, and Prof. S.G. Khomane, "An Onion Grading Machine," International Journal of General Science and Engineering Research (IJGSER), Vol. 3, No. 2, pp. 118-121, 2017.

[4] Y. Adamu, A. A. Adamu, S. I. Kolo, and A. W. Nnanna, "Development of an Automated Fruit Sorting Machine using an Embedded System (Arduino Mega Based)," International Journal of Scientific \& Engineering Research, vol. 10, no. 6, p. 1099, Jun. 2019.

[5] Manning, K, "Soft fruits, biochemistry of fruit ripening," 1996, Chapman and Hall, London, UK.

[6] T. Ishikawa, A. Hayashi, S. Nagamatsu, et al., "Classification of Strawberry Fruit Shape by Machine Learning," The International Archives of the Photogrammetry, Remote Sensing and Spatial Information Sciences, Vol. XLII-2, 2018.

[7] O. Mahendra, H. F. Pardede, R. Sustika, dan R. B. S. Kusumo, "Comparison of Features for Strawberry Grading Classification with Novel Dataset," Conference: 2018 International Conference on Computer, Control, Informatics and its Applications (IC3INA), Nov. 2018.

[8] P. Ibba, C. Tronstad, R. Moscetti, et al., "Supervised binary classification methods for strawberry ripeness discrimination from bioimpedance data,". Sci. Rep., Vol. 11, 11202, 2021. 